\title{
SEBARAN RUMAH TANGGA USAHA PERTANIAN DI KALIMANTAN TIMUR
}

\author{
Karmini $^{1}$ \\ ${ }^{1}$ Jurusan Agribisnis, Fakultas Pertanian, Universitas Mulawarman. \\ Jalan Pasir Balengkong, Kampus Gunung Kelua, Samarinda, Kalimantan Timur, \\ Indonesia, 75119. Telp: +62541749161, Fax: +62541738341. \\ E-Mail: karmini.kasiman@yahoo.com
}

\begin{abstract}
ABSTRAK
Sebaran Rumah Tangga Usaha Pertanian di Kalimantan Timur. Hasil Sensus Pertanian tahun 2003 dan 2013 menunjukkan jumlah rumah tangga pertanian pada tahun 2013 (22\% dari total rumah tangga) di Kalimantan Timur menurun dibandingkan tahun 2003 (34,85\%). Penurunan jumlah rumah tangga pertanian dapat berdampak pada kuantitas dan kualitas produksi pertanian yang dihasilkan setiap kota/kabupaten. Tujuan studi ini adalah untuk mengetahui jumlah dan pertumbuhan Rumah Tangga Usaha Pertanian (RTUP) di Kalimantan Timur serta sebaran RTUP tahun 2003 dan 2013. Penelitian dilaksanakan pada bulan Maret Juni 2017 di Kota Samarinda, Provinsi Kalimantan Timur, Indonesia. Data sekunder dikumpulkan dalam penelitian ini. Analisis data menggunakan statistik deskriptif dan uji $t$. Hasil studi menunjukkan bahwa jumlah RTUP di Kalimantan Timur pada tahun 2003 dan 2013 berturut-turut adalah 203.179 rumah tangga dan 180.614 rumah tangga. Berarti terjadi pertumbuhan negatif jumlah RTUP di Kalimantan Timur sebesar $11,11 \%$ dalam kurun waktu 10 tahun tersebut dan rumah tangga pertanian tersebar tidak merata di seluruh kota/kabupaten di Kalimantan Timur.
\end{abstract}

Kata kunci : Kalimantan Timur, rumah tangga, sebaran, usaha pertanian.

\begin{abstract}
Distribution of Agricultural Business Household in East Kalimantan. The results of Agricultural Cencus 2003 and 2013 showed that the number of farm household in 2013 in East Kalimantan (22.00\% of total household) decreased if it compared than that in 2003 (34.85\%). The decrease of total farm household can impact on quantity and quality of agricultural products which produced in every city/district. The aims of this study were to know the number and growth of Agricultural Business Household (ABH) in East Kalimantan and its distribution in 2003 and 2013. The study was conducted from March to June 2017 in Samarinda City, East Kalimantan Province, Indonesia. Secondary data were collected in this study. Analysis of data used descriptive statistic and $t$ test. The results of study showed that the ABH numbers in East Kalimantan in 2003 and 2013 were 203,179 households and 180,614 households. It meant there was negative growth of total $\mathrm{ABH}$ in East Kalimantan as many as $-11.11 \%$ during 10 years and $\mathrm{ABH}$ was not equally distribute in every city/district in East Kalimantan.
\end{abstract}

Key words : distribution, East Kalimantan, farm business, household.

\section{PENDAHULUAN}

Pertanian berperan penting dalam perekonomian masyarakat. Kontribusi Sektor Pertanian terhadap pembentukan Produk Domestik Regional Bruto (PDRB) Kalimantan Timur adalah 5,93\% pada tahun 2003. Namun, terjadi penurunan kontribusi sektor pertanian dalam kurun waktu 10 tahun. Hal tersebut ditunjukkan dengan besaran kontribusi sektor pertanian menjadi hanya $5,81 \%$ tahun 2013. Data menunjukkan PDRB dari Sektor Pertanian atas dasar harga konstan tahun 2003 dan 2013 di Kalimantan Timur berturut-turut adalah Rp4.903.108,00 juta dan Rp7.216.901,00 juta (Badan Pusat Statistik Provinsi 
Kalimantan Timur (BPS Prov Kaltim), 2014a).

Banyak faktor yang dapat menjadi penyebab turunnya peran sektor pertanian di Kalimantan Timur. Salah satunya adalah menurunnya produksi pertanian yang dihasilkan oleh petani-petani di daerah. Petani-petani berada dalam rumah tangga-rumah tangga yang melakukan aktivitas pada kegiatan pertanian. Rumah tangga pertanian merupakan sumber faktor produksi tenaga kerja atau sumber daya manusia di kegiatan pertanian. Tidak hanya sebagai tenaga kerja, sebagaian dari mereka juga melakukan investasi pada berbagai kegiatan pertanian.

Hasil studi yang telah dilalukan menunjukkan investasi pada kegiatan pertanian tanaman pangan dan hortikultura dilakukan untuk mengembangkan usahatani padi sawah dan padi ladang, sayur-sayuran, dan buah-buahan (Karmini, 2014). Selain tanaman pangan dan hortikultura, berbagai jenis tanaman perkebunan dibudidayakan oleh petani di Kalimantan Timur. Tanaman tersebut antara lain kelapa sawit, pinang, kayu manis, panili, jahe, jambu mete, aren, kakao, kelapa, cengkeh, kopi, lada, karet, kemiri, dan kapuk (Karmini, 2015). Dengan demikian jumlah dan sebaran rumah tangga pertanian akan menentukan jumlah penawaran tenaga kerja pertanian dan jumlah produksi pertanian dari kegiatan investasi yang mereka lakukan.

Pada tahun 2003 dilakukan Sensus Pertanian di Kalimantan Timur. Kegiatan tersebut dilakukan kembali pada 10 tahun kemudian yaitu pada tahun 2013. Sensus Pertanian mengumpulkan berbagai data yang berkaitan dengan kegiatan petanian. Hasil Sensus Pertanian menunjukkan bahwa jumlah rumah tangga di Kalimantan Timur pada tahun 2003 dan 2013 berturut-turut adalah 582.927 rumah tangga dan
820.888 rumah tangga. Sementara itu jumlah rumah tangga pertanian pada tahun 2003 hanya $34,85 \%$ dari total rumah tangga di Kalimantan Timur dan menurun menjadi $22,00 \%$ pada tahun 2013 (BPS Prov Kaltim, 2014a).

Keberadaan rumah tangga pertanian terdapat di seluruh kota/kabupaten di Kalimantan Timur. Perubahan jumlah rumah tangga pertanian dapat berdampak pada dan kualitas produksi pertanian yang dihasilkan setiap kota/kabupaten karena rumah tangga pertanian merupakan sumber tenaga kerja dan pelaku investasi di bidang pertanian. Tujuan studi ini adalah untuk mengetahui jumlah dan pertumbuhan Rumah Tangga Usaha Pertanian (RTUP) di Kalimantan Timur serta sebaran RTUP tahun 2003 dan 2013.

\section{METODA PENELITIAN}

\subsection{Tempat dan Waktu}

Lokasi penelitian pada BPS Prov Kaltim di Kota Samarinda, Provinsi Kalimantan Timur, Indonesia. Pada bulan MaretJuni 2017.

\subsection{Metode Pengumpulan Data}

Data yang dikumpulkan dari penelitian ini adalah data sekunder. Data sekunder diperoleh dari BPS Prov Kaltim. Data yang dikumpulkan antara lain jumlah RTUP menurut subsektor, rata-rata pendapatan RTUP, jumlah RTUP setiap kota/kabupaten, distribusi RTUP, dan pertumbuhan RTUP di Kalimantan Timur.

\subsection{Metode Analisis Data}

Analisis data untuk menggambarkan tentang jumlah RTUP dan pertumbuhan RTUP di Kalimantan Timur menggunakan statistik deskriptif berupa jumlah, rata-rata, dan persentase. Sebaran RTUP di 
Kalimantan Timur tahun 2003 dan 2013 diketahui dengan melakukan analisis data menggunakan uji $t$ satu variabel bebas. Hipotesis yang diajukan dalam studi ini adalah:

$\mathrm{H}_{0}$ : Rumah tangga pertanian tersebar merata di seluruh kota/kabupaten di Kalimantan Timur.

$\mathrm{H}_{\mathrm{a}}$ : Rumah tangga pertanian tersebar tidak merata di seluruh kota/kabupaten di Kalimantan Timur. Pengujian hipotesis menggunakan data hasil Sensus Pertanian tahun 2003 dan 2013. Menurut Riduwan dan Sunarto (2007), jika analisis perbandingan satu variabel bebas atau dikenal dengan uji $t$ dengan standar deviasi populasi diketahui, maka uji $t$ dilakukan dengan menggunakan rumus $z_{\text {hitung }}$ sebagai berikut:

$$
z_{\text {hitung }}=\frac{\bar{x}-\mu_{0}}{\frac{\sigma}{\sqrt{N}}}
$$

di mana:

$z_{\text {hitung }}=$ harga yang dihitung dan menunjukkan standar deviasi pada distribusi normal (tabel $z$ );
$\bar{X}=$ rata-rata nilai yang diperoleh dari hasil pengumpulan data;

$\mu_{0}=$ rata-rata nilai yang dihipotesiskan;

$\sigma=$ standar deviasi populasi yang telah

diketahui;

$N=$ jumlah populasi penelitian.

\section{HASIL PENELITIAN DAN PEMBAHASAN}

\subsection{Rumah Tangga Usaha Pertanian \\ (RTUP) di Kalimantan Timur}

Jumlah RTUP di Kalimantan Timur pada tahun 2003 adalah 203.179 rumah tangga. Jumlah tersebut menurun menjadi hanya 180.614 rumah tangga pada tahun 2013. Anggota-anggota dari rumah tangga pertanian memiliki satu atau beberapa usaha yang bergerak pada bidang pertanian. Pada tahun 2003, usaha yang paling banyak digeluti RTUP adalah di bidang hortikultura, sementara pada tahun 2013 adalah usaha di bidang perkebunan. Usaha di perikanan dan kehutanan tidak banyak diminati oleh anggota RTUP di daerah studi (Tabel 1).

Tabel 1. Jumlah Rumah Tangga Usaha Pertanian menurut subsektor berdasarkan hasil Sensus Pertanian 2003 dan 2013

\begin{tabular}{clrr}
\hline No. & Subsektor & 2003 & 2013 \\
\hline 1 & Tanaman Pangan & 99.784 & 83.564 \\
2 & Hortikultura & 100.628 & 64.713 \\
3 & Perkebunan & 72.849 & 100.281 \\
4 & Peternakan & 75.326 & 57.437 \\
5 & Perikanan & 33.364 & 33.949 \\
6 & Kehutanan & 35.534 & 16.536 \\
\hline & Jumlah & 417.485 & 356.480 \\
\hline & Kalimantan Timur & 203.179 & 180.614 \\
\hline
\end{tabular}

Sumber: BPS Prov Kaltim (2014a).

Jumlah RTUP yang memiliki kegiatan usaha di subsektor tanaman pangan di Kalimantan Timur pada tahun 2013 sebanyak 83.564 rumah tangga. Hasil penelitian menunjukkan bahwa rumah tangga petani padi di Kalimantan Timur memiliki beberapa karakteristik sosial ekonomi. Sebagian besar anggota dari rumah tangga petani padi berasal dari komunitas suku Jawa. Laki-laki 
memiliki jumlah dominan di rumah tangga petani padi. Kepala rumah tangga memegang peranan sebagai manajer dalam usaha tani padi. Sebagian besar rumah tangga petani padi memiliki jumlah anggota keluarga antara 3-4 orang dan sebagian besar telah menikah (Karmini dan Isa, 2012).

Salah satu faktor yang menjadi pertimbangan anggota RTUP untuk terlibat pada kegiatan pertanian maupun non pertanian adalah peluang pendapatan yang diperoleh dari kegiatan usaha yang dilakukan. Hasil Sensus Pertanian 2013 dan Survei Pendapatan Rumah Tangga Usaha Pertanian 2013 menunjukkan bahwa sekitar 46,69\% pendapatan RTUP diperoleh dari usaha di sektor pertanian. Usaha di luar sektor pertanian hanya menyumbang sekitar $9,26 \%$ terhadap pendapatan RTUP di mana lebih rendah dibandingkan kontribusi pendapatan sebagai buruh di luar pertanian $(21,98 \%)$ dan pendapatan/penerimaan lain dan transfer $(14,76 \%)$. Pekerjaan sebagai buruh pertanian memberikan kontribusi rata-rata sebesar Rp3.362.270,00 kepada RTUP. Rata-rata pendapatan RTUP di Kalimantan Timur pada tahun 2012 adalah sebesar Rp46.035.010,00 (Tabel 2).

Tabel 2. Rata-rata pendapatan Rumah Tangga Usaha Pertanian berdasarkan hasil Sensus Pertanian 2013 dan Survei Pendapatan Rumah Tangga Usaha Pertanian 2013

\begin{tabular}{rlrr}
\hline No. & Sumber pendapatan/penerimaan & $\begin{array}{c}\text { Rata-rata pendapatan } \\
\text { (Rp ribu) }\end{array}$ & Persentase (\%) \\
\hline 1 & Usaha di sektor pertanian & $21.495,45$ & 46,69 \\
2 & Usaha di luar sektor pertanian & $4.264,28$ & 9,26 \\
3 & Pendapatan/penerimaan lain dan transfer & $6.793,46$ & 14,76 \\
4 & Buruh pertanian & $3.362,27$ & 7,30 \\
5 & Buruh di luar pertanian & $10.119,55$ & 21,98 \\
\hline & Jumlah & $46.035,01$ & 100,00 \\
\hline
\end{tabular}

Sumber: BPS Prov Kaltim (2014b).

\subsection{Pertumbuhan Rumah Tangga Usaha Pertanian (RTUP) di Kalimantan Timur}

Dalam kurun waktu 10 tahun ternyata terjadi perubahan jumlah RTUP di Kalimantan Timur. Jika pada tahun 2003, jumlah RTUP mencapai 203.179 rumah tangga maka jumlah tersebut menurun sebesar $-11,11 \%$ menjadi 180.614 rumah tangga. Penurunan jumlah RTUP terjadi di 11 kota/kabupaten di Kalimantan Timur, sedangkan peningkatan jumlah RTUP hanya terjadi di Kota Bontang (28,56\%), Kabupaten Penajam Paser Utara (11,55\%), dan
Kabupaten Kutai Timur (1,22\%) (Tabel 3). Pertumbuhan yang negatif dari jumlah RTUP yang ada di provinsi ini dapat disebabkan oleh berbagai faktor antara lain ketersediaan lapangan kerja di luar sektor pertanian, luas lahan pertanian yang ada dan dimanfaatkan masyarakat, ketersediaan sarana dan prasarana di tingkat lokal, pasar untuk produk pertanian, dan lain-lain. Pertumbuhan negatif dari RTUP berdampak pada menurunnya ketersediaan tenaga kerja untuk pekerjaan di bidang pertanian dan hal ini pada akhirnya dapat mempengaruhi kegiatan produksi hasil pertanian. 
Tabel 3. Distribusi dan pertumbuhan Rumah Tangga Usaha Pertanian (RTUP) di Kalimantan Timur berdasarkan hasil Sensus Pertanian 2003 dan 2013

\begin{tabular}{|c|c|c|c|c|c|}
\hline \multirow[t]{2}{*}{ No. } & \multirow[t]{2}{*}{ Kota/Kabupaten } & \multicolumn{3}{|c|}{ Jumlah RTUP } & \multirow{2}{*}{$\begin{array}{r}\text { Pertumbuhan } \\
\%\end{array}$} \\
\hline & & 2003 & 2013 & Absolut & \\
\hline 1 & Paser & 27.475 & 26.846 & -629 & $-2,29$ \\
\hline 2 & Kutai Barat & 22.519 & 18.833 & -3686 & $-16,37$ \\
\hline 4 & Kutai Timur & 22.786 & 23.065 & 279 & 1,22 \\
\hline 5 & Berau & 15.728 & 15.055 & -673 & $-4,28$ \\
\hline 6 & Penajam Paser Utara & 15.596 & 17.398 & 1802 & 11,55 \\
\hline 9 & Samarinda & 20.489 & 10.261 & -10228 & $-49,92$ \\
\hline \multirow[t]{2}{*}{10} & Bontang & 2.910 & 3.741 & 831 & 28,56 \\
\hline & Kalimantan Timur & 203.179 & 180.614 & -22565 & $-11,11$ \\
\hline
\end{tabular}

Sumber: BPS Prov Kaltim (2014a).

\subsection{Sebaran Rumah Tangga Usaha} Pertanian (RTUP) di Kalimantan Timur Tahun 2003

Hasil analisis data menunjukkan bahwa $z_{\text {hitung }}(3,95)>z_{\text {tabel }}(0,49)$ berarti $\mathrm{H}_{0}$ ditolak dan $\mathrm{H}_{\mathrm{a}}$ diterima atau rumah tangga pertanian tersebar tidak merata di seluruh kota/kabupaten di Kalimantan Timur berdasarkan hasil Sensus Pertanian tahun 2003. Data pada Tabel 4 menunjukkan jumlah RTUP di suatu kota/kabupaten berbeda dengan kota/kabupaten lainnya. Besaran distribusi RTUPpun bervariasi antara $1,43 \%$ - 29,85\%. Kabupaten Kutai Kartanegara memiliki RTUP yang paling banyak jumlahnya diantara kota/kabupaten di Kalimantan Timur sedangkan Kota Bontang memiliki RTUP yang paling sedikit. Jumlah dan distribusi RTUP dipengaruhi oleh berbagai faktor antara lain jumlah penduduk di suatu kota/kabupaten, luas lahan pertanian yang ada di suatu kota/kabupaten, dan peluang/potensi usaha pertanian di suatu daerah.

Tabel 4. Jumlah dan distribusi Rumah Tangga Usaha Pertanian (RTUP) di Kalimantan Timur berdasarkan hasil Sensus Pertanian 2003

\begin{tabular}{clrr}
\hline No. & \multicolumn{1}{c}{ Kota/Kabupaten } & Jumlah & Distribusi (\%) \\
\hline 1 & Paser & 27.475 & 13,52 \\
2 & Kutai Barat & 22.519 & 11,08 \\
3 & Kutai Kartanegara & 60.641 & 29,85 \\
4 & Kutai Timur & 22.786 & 11,21 \\
5 & Berau & 15.728 & 7,74 \\
6 & Penajam Paser Utara & 15.596 & 7,68 \\
7 & Mahakam Ulu & 4.457 & 2,19 \\
8 & Balikpapan & 10.578 & 5,21 \\
9 & Samarinda & 20.489 & 10,08 \\
10 & Bontang & 2.910 & 1,43 \\
\hline & Kalimantan Timur & 203.179 & 100,00 \\
\hline
\end{tabular}

Sumber: BPS Prov Kaltim (2014a).

\subsection{Sebaran Rumah Tangga Usaha} Pertanian (RTUP) di Kalimantan Timur Tahun 2013

Hasil analisis data Sensus Pertanian tahun 2013 menunjukkan bahwa $z_{\text {hitung }}(3,66)>z_{\text {tabel }}(0,49)$ berarti $\mathrm{H}_{0}$ ditolak dan $\mathrm{H}_{\mathrm{a}}$ diterima atau rumah tangga pertanian tersebar tidak merata di seluruh kota/kabupaten di Kalimantan Timur. Data pada Tabel 5 menunjukkan RTUP banyak terdapat di Kabupaten Kutai Kartanegara (31\%), Paser $(14,86 \%)$, Kutai Timur $(12,77 \%)$, dan Kutai Barat $(10,43 \%)$. Sedangkan pada daerah kota/kabupaten lain jumlahnya hanya sedikit yaitu di bawah $10 \%$. 
Walaupun di daerah perkotaan jumlah rumah tangga besar namun jumlah RTUP kecil dikarenakan jumlah penduduk yang terlibat dalam kegiatan pertanian juga sedikit.

Tabel 5. Jumlah dan distribusi Rumah Tangga Usaha Pertanian (RTUP) di Kalimantan Timur berdasarkan hasil Sensus Pertanian 2013

\begin{tabular}{clrr}
\hline No. & \multicolumn{1}{c}{ Kota/Kabupaten } & Jumlah & Distribusi (\%) \\
\hline 1 & Paser & 26.846 & 14,86 \\
2 & Kutai Barat & 18.833 & 10,43 \\
3 & Kutai Kartanegara & 56.120 & 31,07 \\
4 & Kutai Timur & 23.065 & 12,77 \\
5 & Berau & 15.055 & 8,34 \\
6 & Penajam Paser Utara & 17.398 & 9,63 \\
7 & Mahakam Ulu & 3.275 & 1,81 \\
8 & Balikpapan & 6.020 & 3,33 \\
9 & Samarinda & 10.261 & 5,68 \\
10 & Bontang & 3.741 & 2,07 \\
\hline & Kalimantan Timur & 180.614 & 100,00 \\
\hline
\end{tabular}

Sumber: BPS Prov Kaltim (2014a).

\section{KESIMPULAN}

Jumlah RTUP di Kalimantan Timur pada tahun 2003 dan 2013 berturut-turut adalah 203.179 rumah tangga dan 180.614 rumah tangga. Dengan demikian, dalam kurun waktu 10 tahun terjadi pertumbuhan negatif jumlah RTUP di Kalimantan Timur sebesar $-11,11 \%$. Rumah tangga pertanian tersebar tidak merata di seluruh kota/kabupaten di Kalimantan Timur berdasarkan hasil Sensus Pertanian tahun 2003 ( $z_{\text {hitung }}$ $\left.(3,95)>z_{\text {tabel }}(0,49)\right)$ dan tahun 2013 $\left(z_{\text {hitung }}(3,66)>z_{\text {tabel }}(0,49)\right)$.

\section{DAFTAR PUSTAKA}

Badan Pusat Statistik Provinsi Kalimantan Timur (BPS Prov Kaltim). 2014a. Potensi Pertanian Provinsi Kalimantan Timur. Analisis Hasil Pencacahan Lengkap Sensus Pertanian 2013. BPS Prov Kaltim, Samarinda.

BPS Prov Kaltim. 2014b. Potret Usaha Pertanian Provinsi Kalimantan Timur Menurut Subsektor (Hasil Pencacahan Lengkap Sensus Pertanian 2013 dan Survei Pendapatan Rumah Tangga Usaha Pertanian 2013). BPS Prov Kaltim, Samarinda.
Karmini. 2014. Analisis investasi pada kegiatan pertanian tanaman pangan dan hortikultura di Kabupaten Kutai Kartanegara. Riset Kaltim 2(4): 13-27.

Karmini. 2015. Studi pengembangan usaha perkebunan di Kabupaten Kutai Kartanegara. Agrifor 14(1): 69-78.

Karmini, Isa AHM. 2012. Characteristics of paddy farmers households in East Kalimantan, Indonesia. The $4^{\text {th }}$ Regional Conference Natural Resources in the Tropics (Ntrop4) Sustaining Tropical Natural Resources through Innovations, Technologies, and Practices. Universiti Malaysia Sarawak, Malaysia, $19^{\text {th }}-21^{\text {st }}$ September 2012.

Riduwan dan Sunarto. 2007. Pengantar Statistika untuk Penelitian Pendidikan, Sosial, Ekonomi, Komunikasi, dan Bisnis. Alfabeta, Bandung. 